\title{
Morphological and ecophysiological plasticity in dioecious plant Populus tomentosa under drought and alkaline stresses
}

\author{
Y.W. LU, ${ }^{* * *}$, X.L. MIAO*, Q.Y. SONG ${ }^{*}$, S.M. PENG ${ }^{* * *}$, and B.L. DUAN ${ }^{* *+}$ \\ School of Life Sciences, Liaocheng University, Liaocheng 252059, China* \\ Key Laboratory of Mountain Surface Processes and Ecological Regulation, Institute of Mountain Hazards \\ and Environment, Chinese Academy of Sciences, Chengdu 610041, China** \\ College of Materials and Chemistry \& Chemical Engineering, Chengdu University of Technology, \\ Chengdu 610059, China ${ }^{* * *}$
}

\begin{abstract}
Morphological and ecophysiological traits showed by male and female Populus tomentosa Carr. trees were studied under various degrees of water and alkaline stresses. The results showed that different adaptations to drought and alkaline stresses were adopted by each gender; males possessed a much higher tolerance to both stresses compared to females. In contrast to females, the males exhibited a lower inhibition in total biomass, total leaf area, net photosynthetic rate, stomatal conductance, leaf carbon and nitrogen concentrations as well as water- and nitrogen-use efficiency in response to drought and alkaline stresses. Nevertheless, compared to the males, the females showed a higher plasticity in root biomass/shoot biomass ratio, fine root/coarse root ratio, and intrinsic water-use efficiency, indicating that the males and females differed in some of trade-offs between growth and stress defence to maximize water and nitrogen gains under both stress conditions.
\end{abstract}

Additional key words: alkaline stress; cuttings; drought; gender; plasticity index; poplar.

\section{Introduction}

Approximately 932 million ha of land is subjected to soil salinity and alkalinity stresses worldwide. These soils are characterized by high $\mathrm{pH}$, poor fertility, and an extremely low water-infiltration capacity, thereby reducing the yield of crops and forests on approximately 100 million ha throughout Asia (Rao et al. 2008). It is difficult to determine the alkalinity tolerance of trees and their corresponding ecophysiological adaptations, particularly for long-lived species, and it is even more difficult in complex environments, where drought, flooding, and other stresses co-occur (James et al. 2005). Phenotypic plasticity (i.e., changes in the phenotypic expression of a genotype in response to environmental factors; Valladares et al. 2000, West-Eberhard 2003, Godoy et al. 2011) is widely expected to have evolutionary consequences. Different resource allocation could lead to males and females of dioecious trees that differ from one another in terms of photosynthetic capacity (Dawson and Bliss 1989) and water and nutrient relations (Dawson and Ehleringer 1993) as well as in long-term indicators of physiological traits, such as tissue isotope composition.

The analysis of stable isotopes can provide vital

Received 24 August 2017, accepted 9 March 2018, published as online-first 27 June 2018.

${ }^{+}$Corresponding author; e-mail: duanbl@imde.ac.cn.

Abbreviations: $\mathrm{A}_{1}$ - low alkaline stress; $\mathrm{A}_{2}$ - high alkaline stress; $\mathrm{C}$ - leaf carbon concentration; DM - dry mass; DS - drought stress; Fine/Coarse ratio - fine roots/coarse roots; $g_{\mathrm{s}}$ - stomatal conductance; LAtotal - total leaf area; LAR - leaf area ratio; LMA - leaf mass per area; $\mathrm{N}$ - leaf nitrogen concentrations; NS - non-alkaline-stressed; $\mathrm{N}_{\mathrm{T}}$ - total plant nitrogen concentrations; NUE - nitrogen-use efficiency, NUpE - nitrogen-uptake efficiency; PI - plasticity index; $P_{\mathrm{N}}$ - net photosynthetic rate; PNUE - photosynthetic nitrogen-use efficiency; R/S ratio - root biomass/shoot biomass ratio; $\mathrm{SRL}_{\mathrm{f}}$ - the ratio of fine root length to dry mass of fine roots; $\mathrm{TB}$ - total biomass; $\mathrm{WUE}_{\mathrm{i}}$ - intrinsic water-use efficiency; WW - well watered; $\delta^{13} \mathrm{C}$ - carbon isotope composition; $\delta^{15} \mathrm{~N}$ - nitrogen isotope composition; $\delta^{15} \mathrm{~N}_{1}$ - pretreated with ${ }^{15} \mathrm{NH}_{4} \mathrm{Cl}$ fertilizer; $\delta^{15} \mathrm{~N}_{2}$ - pretreated with $\mathrm{Na}^{15} \mathrm{NO}_{3}$ fertilizer.

Acknowledgements: This work was financially supported by the National Natural Science Foundation of China (No. 31100456, No. 31370607, 3137070605).

Author contribution statement: Yanwei Lu contributed to all the experimental process, conducting the experiment, dealing with the data and writing the paper. Xiulian Miao, Qingyun Song, Shuming Peng mainly contributed to the experimental process. Baoli Duan supervised the research work and revised the manuscript. 
information about ecology and dynamics of plant systems and their interrelations with the surrounding environment (Ometto et al. 2006). For example, carbon isotope $\left(\delta^{13} \mathrm{C}\right)$ values have been proven to be associated with water-use efficiency (WUE) (Bonal et al. 2000), while nitrogen isotope $\left(\delta^{15} \mathrm{~N}\right)$ abundance analysis can provide information on the nutrient pools used by trees (Wanek and Zotz 2011). In general, more negative $\delta^{13} \mathrm{C}$ values are usually associated with lower WUE (Li et al. 2000), while more $\delta^{15} \mathrm{~N}$ values indicate higher nitrogen-uptake efficiency (NUpE) (Millard and Grelet 2010). Apart from aboveground measures, root metrics, such as the fine roots/ coarse roots ratio (Fine/Course ratio) and specific root length of fine root $\left(\mathrm{SRL}_{\mathrm{f}}\right)$, which primarily depends on the overall contribution of fine roots, are positively related to root water- and nutrient-uptake capacity (Sudmeyer et al. 2004, Dong et al. 2015).

Dioecious plants represent only $6 \%$ of flowering angiosperm species (Renner and Ricklefs 1995) but are vital to terrestrial ecosystems. Owing to their biased sex ratio and gender-specific variation in balancing growth and reproduction under different environments (Dawson and Geber 1999, Obeso 2002), dioecious plants serve as good models for detecting trade-offs in resource allocation (Cepeda-Cornejo and Dirzo 2010). Given the respective resource costs of reproduction, each gender adopts resource-allocation strategies that suit it; thus, females allocate more resources to reproduction and defence, whereas males allocate more resources to growth (Obeso 2002, Stehlik et al. 2008). Such resource-allocation patterns might differentiate adaptive traits between females and males (Geber et al. 1999). Importantly, females are more abundant in rich-resource habitats, whereas males are more tolerant to adverse conditions (Ortiz et al. 2002). Many studies have revealed differences in resource-allocation trade-offs between sexes related to drought, salinity, elevated temperature, light, and nutrient surpluses, etc., but the results vary among studies (Delph

\section{Materials and methods}

Plant material and experimental design: The experimental material consisted of 240 cuttings (120 males and 120 females) collected from 60 trees (30 of each sex) sampled from 15 populations at the flowering stage in the Yellow River alluvial plain habitats (Liaocheng, $36^{\circ} 45^{\prime} \mathrm{N}$, $\left.115^{\circ} 97^{\prime} \mathrm{E}\right)$ in Shandong Province, China. The mother trees selected were from distant locations to ensure a diversity of genotypes. The mean annual rainfall and mean annual temperature of this semiarid continental area are $578.4 \mathrm{~mm}$ and $13.1^{\circ} \mathrm{C}$, respectively. Healthy cuttings of uniform height were selected and transplanted into $10-\mathrm{L}$ plastic pots (one cutting per each pot). The average mean height of the selected trees was $48.60 \pm 2.30 \mathrm{~cm}$ for females and $49.80 \pm 2.60 \mathrm{~cm}$ for males, while the average diameter of the selected trees was $5.60 \pm 0.30 \mathrm{~mm}$ for the females and $5.80 \pm 0.40 \mathrm{~cm}$ for the males. Each pot was filled with
1990, Montesinos et al. 2012, Zhao et al. 2012, Randriamanana et al. 2014, Li et al. 2016). In response to long-term N storage increases, female Juniperus thurifera trees benefit more from $\mathrm{N}$ surpluses than do males (Montesinos et al. 2012). Meanwhile, no gender differences have also been reported owing to their own strategies to compensate for reproductive costs (Delph 1990).

Chinese white poplar (Populus tomentosa Carr.) is a dioecious, native tree species widely distributed in China. These trees are fast growing, and they have important ecological and economical characteristics and superior wood quality (He et al. 2005). In recent years, enormous climatic threats impacting $P$. tomentosa biomass have increased in severity, along with changes in land use and increased habitat destruction (Munns 2011, Behnke et al. 2013). Given the respective resource costs of reproduction, each gender adopts appropriate resource-allocation strategies (Chen et al. 2015). Our previous studies have shown that male $P$. tomentosa plants are more tolerant than females towards salt, with a higher degree of root colonization by arbuscular mycorrhizal symbiosis (Lu et al. 2014). In the present study, we examined plant growth and biomass allocation, gas exchange, leaf $\mathrm{C}$ and $\mathrm{N}$ concentrations, water- and nitrogen-use efficiency, and carbon and nitrogen isotope compositions in female and male $P$. tomentosa cuttings under various degrees of water stress and alkalinity. Additionally, the plasticity in leafand plant-level traits was also measured for both genders. The objectives of the present study were to characterize the response patterns of both genders of $P$. tomentosa to soil alkalinity and drought and to gain further insight into these response mechanisms.

Specifically, we aimed to address the following questions: (1) Do P. tomentosa genders exhibit morphological and ecophysiological differences in response to drought and alkaline stresses? (2) What are the trade-offs between growth and stress defence for each gender?

homogenized brown soil, and $12 \mathrm{~g}$ of slow-release fertilizer (compound fertilizer, 13:10:14 NPK plus oligoelements; Luxi Chemical Company, Ltd., China) was added to meet the plant macronutrient needs. Hoagland's basic nutrient solution was also prepared and added to satisfy the plant micronutrient requirements. The plants were grown at Liaocheng University in a semi-controlled greenhouse to avoid the effects of rainfall. The daytime temperature ranged from $10-36^{\circ} \mathrm{C}$, the night temperature ranged from $9-18^{\circ} \mathrm{C}$, and the relative humidity ranged from $45-80 \%$ throughout the entire experimental period.

Two watering regimes were applied in our study. The first regime constituted well-watered (WW) conditions: 60 pots of each gender were weighed every other day and were watered to $100 \%$ of field capacity (FC) by supplying water equal to that lost by transpiration; in this case, the 
soil water content was always maintained at volumetric content of $32.3 \%$, as measured by a portable soil moisture detector (Trime-IDR, IMKO Inc., Germany) with a TDR pico soil moisture probe. The second regime constituted drought-stressed (DS) conditions: 60 pots of each gender were weighed every other day and were watered to $40 \%$ of field capacity (FC) by supplying water equal to that lost by transpiration; in this case, the soil water content was always maintained at a volumetric content of $13.8 \%$. In order to simulate real conditions, we selected three alkaline levels that matched measured field conditions in which $P$. tomentosa naturally occurs. Non-alkaline-stressed (CK) cuttings were irrigated with $250 \mathrm{~mL}$ of Hoagland solution ( $\mathrm{pH}$ 6.0); the low- and high-alkaline-stressed cuttings were irrigated every other day with the same amount of Hoagland solution $(250 \mathrm{~mL})$ containing either $75 \mathrm{mM}\left(\mathrm{Na}_{2} \mathrm{CO}_{3}\right)$ $\mathrm{L}^{-1}\left[\mathrm{pH} 7.78\right.$, the low alkaline stress $\left.\left(\mathrm{A}_{1}\right)\right]$ or 150 $\mathrm{mM}\left(\mathrm{Na}_{2} \mathrm{CO}_{3}\right) \mathrm{L}^{-1}\left[\mathrm{pH} 8.62\right.$, the high alkaline stress $\left.\left(\mathrm{A}_{2}\right)\right]$, respectively. Thus, the experimental layout in our study was completely randomized and involved 12 factorial combinations with three factors: sex (male, female) $\times$ water $(\mathrm{WW}$ and $\mathrm{DS}$ conditions $) \times$ alkalinity $\left(\mathrm{CK}, \mathrm{A}_{1}\right.$, and $A_{2}$ ). Six treatments were applied to the cuttings of each gender:

\begin{tabular}{lll}
\hline Treatment & Water conditions & Alkaline stress \\
\hline $\mathrm{CK}$ & Well-watered & - \\
$\mathrm{WW}+\mathrm{A}_{1}$ & Well-watered & Low \\
$\mathrm{WW}+\mathrm{A}_{2}$ & Well-watered & High \\
$\mathrm{DS}$ & Drought & - \\
$\mathrm{DS}+\mathrm{A}_{1}$ & Drought & Low \\
$\mathrm{DS}+\mathrm{A}_{2}$ & Drought & High
\end{tabular}

Each treatment group included 20 male and 20 female cuttings, which were assigned to five blocks. The five blocks were rotated each week to eliminate potential microenvironmental effects. An empirical relationship between plant fresh mass $(\mathrm{Y}, \mathrm{g})$ and plant height $(\mathrm{X}, \mathrm{cm})$, $\mathrm{Y}=0.975+0.112 \mathrm{X}\left(R^{2}=0.968, P<0.001\right)(\mathrm{Li}$ et al. 2004$)$, was used to correct pot watering amounts for changes in plant biomass. All treated plants were maintained for four months from 1 June to 30 September during the experiment.

Growth and morphological traits: Betwen 28-30 September, all cuttings were harvested and partitioned into leaves, stems, and roots. For the root analysis, two groups were considered: coarse roots (longer than $2 \mathrm{~mm}$ in diameter) and fine roots (shorter than $2 \mathrm{~mm}$ in diameter). The dry mass (DM) was determined after the samples were oven-dried at $70 \pm 2^{\circ} \mathrm{C}$ for $3 \mathrm{~d}$. The total leaf area $\left(\mathrm{LA}_{\text {total }}\right)$ of 20 cuttings was measured using a portable laser area meter (CI-203; CID Inc., Camas, WA, USA). Based on the biomass mass and leaf area, the following primary morphological and structural indices were calculated: leaf mass per area (LMA, leaf biomass per unit leaf area), the leaf area ratio (LAR, leaf area divided by total biomass), the root/shoot ratio $[\mathrm{R} / \mathrm{S}$ ratio, the ratio of root biomass to shoot (leaf + stem) biomass], the fine root biomass/coarse root biomass ratio (Fine/Course ratio) and the specific root length of fine roots $\left(\mathrm{SRL}_{\mathrm{f}}\right.$, the ratio between the length of fine roots and their DM).

Photosynthetic parameters: The photosynthetic rate $\left(P_{\mathrm{N}}\right)$ and stomatal conductance $\left(g_{\mathrm{s}}\right)$ were measured using an open gas-exchange system ( $\mathrm{Li}$-6400, Li-Cor Inc., Lincoln, NE, USA). Five replicates of the second, third, and fourth mature leaf samples were assayed. The measurements were performed from 09:00 to 11:00 in the morning throughout one week. The leaf temperature was $25^{\circ} \mathrm{C}$, the PAR was $1,500 \mu \mathrm{mol}\left(\right.$ photon) $\mathrm{m}^{-2} \mathrm{~s}^{-1}$, the relative air humidity was $70.0 \pm 3.5 \%$, and the ambient $\mathrm{CO}_{2}$ concentration was $400 \pm 5 \mu \mathrm{mol} \mathrm{mol}{ }^{-1}$. The photosynthetic nitrogen-use efficiency (PNUE) was calculated as the ratio of $P_{\mathrm{N}}$ to leaf $\mathrm{N}$, and the intrinsic water-use efficiency $\left(\mathrm{WUE}_{\mathrm{i}}\right)$ was obtained as the ratio of $P_{\mathrm{N}}$ to $g_{\mathrm{s}}$.

Carbon and nitrogen concentrations: Dried leaf samples were homogenized by pulverizing the leaves and sifting the resulting powder through a 20 -mesh screen. The concentrations of carbon (C) and nitrogen (N) were determined using the rapid dichromate oxidation technique (Nelson and Sommers 1982) and the semi-micro Kjeldahl method (Mitchell 1998), respectively.

Carbon and nitrogen isotope compositions: A week before sampling for the $\delta^{15} \mathrm{~N}$ composition analysis, a half of the cuttings was pre-watered with a solution of ${ }^{15} \mathrm{~N}$ ammonium $\left({ }^{15} \mathrm{NH}_{4} \mathrm{Cl}, \delta^{15} \mathrm{~N}_{1}\right)$, and the other half was prewatered with a solution of ${ }^{15} \mathrm{~N}$-nitrate $\left(\mathrm{Na}^{15} \mathrm{NO}_{3}, \delta^{15} \mathrm{~N}_{2}\right)$ through plastic tubes inserted into holes near the roots in each pot (Kalcsits et al. 2015). Samples (100 mg each) of fully expanded leaves were oven-dried at $65^{\circ} \mathrm{C}$ for $2 \mathrm{~d}$ and subsequently pulverized. The amounts of stable carbon and nitrogen isotopes in the combusted samples were measured using an elemental analyser (Flash EA1112 HT, Thermo Finnigan Inc.) coupled with an isotope ratio mass spectrometer (Delta $V$ Advantage, Thermo Fisher Scientific, Inc., USA) in accordance with the methods of Li et al. (2000) and Ometto et al. (2006). The assays were performed at the Chinese Academy of Forestry. The instrumental precision for ${ }^{13} \mathrm{C}$ and ${ }^{15} \mathrm{~N}$ was $0.1 \%$ for the five replicates.

Nitrogen uptake and nitrogen-use efficiency: Nitrogen uptake and nitrogen-use efficiency were represented by the $\mathrm{N}$-uptake efficiency (NUpE) and nitrogen-use efficiency (NUE), respectively. NUpE was calculated as the ratio of the total plant $\mathrm{N}\left(\mathrm{N}_{\mathrm{T}}\right)$ concentration to the fine root biomass, as reported by Hawkins (2007). NUE was calculated as the ratio of total plant biomass to the $\mathrm{N}_{\mathrm{T}}$ concentration, as described by Bernacchi et al. (2007). 
Calculation of the plasticity index (PI): Phenotypic plasticity is indicated by plasticity index (PI) values, as these values better represent the reaction norm and exhibit little response to variance between two samples (Godoy et al. 2011). The PI values were obtained from the ratio between the highest and the lowest mean values of the ecophysiological variables at all treatments and the highest mean value of all studied variables [i.e., (the highest valuethe lowest value)/the highest value] in accordance with the methods of Valladares et al. (2006) in order to compare the plasticity of females and males at both the leaf and plant levels. Additionally, the mean plasticity index was calculated by averaging the PI of all the above mentioned 20 variables for males and females.

Statistical analyses: All measurements were tested by a two-way analysis of variance ( $A N O V A)$ for the effects of drought and alkaline stress in each sex. Before the two-way

\section{Results}

Effects of drought and alkaline stress on growth and morphological traits: Leaves, stems, total biomass (TB) and total leaf area $\left(\mathrm{LA}_{\text {total }}\right)$ showed a significant decrease in response to drought and alkaline stress conditions in both sexes (Table 1). The 'drought $\times$ alkaline' interaction reflected a cumulative effect of drought and alkaline stress, indicated by the lower values of $\mathrm{LA}_{\text {total }}$ and $\mathrm{TB}$ under the combined stress conditions than under each individual stress conditions. There was a significant 'sex $\times$ alkaline' interactive effect for the above four traits because of a much larger decrease in females than males at high and low alkaline levels. There were similar trends between the two sexes in four traits (stem biomass was excluded), as 'sex $\times$ drought' interactive effects were not statistically significant for this parameter (Table 1 ).

The 'drought $\times$ alkaline' interaction also reflected a cumulative effect under both factors, as higher values of LMA occurred under combined stress conditions than under each individual stress. However, a significant 'sex $x$ drought $\times$ alkaline' interaction resulted in a larger change in LMA in the females than in the males (Table 1). Alkaline stress increased the R/S ratio to a greater extent in the females than in the males, which indicates the existence of a significant 'sex $\times$ alkaline' effect. A significant interaction of the 'drought $\times$ alkaline' effect induced much higher increases in the Fine/Course ratio and $\mathrm{SRL}_{\mathrm{f}}$ under the combination of drought and alkaline stress than under drought and alkalinity individually. Genders significantly differed in their Fine/Course ratio and $\mathrm{SRL}_{\mathrm{f}}$ in response to drought and alkaline stress (significant 'sex $\times$ drought' and 'sex $\times$ alkaline' interactions occurred); however, the two indices exhibited different trends, such that a greater increase was observed in the Fine/Course ratios for the females, whereas a greater increase was observed in $\mathrm{SRL}_{\mathrm{f}}$ for the males (Table 1).
$A N O V A$, an $A N O V A$ of the populations (site) and tree effects was performed. Post-hoc comparisons were tested using Tukey's test at a significance level of $P<0.05$. Differences between PI values obtained for males and females were assessed using an independent-sample $t$-test. Statistical significance was concluded when $P<0.05$. All the above analyses were performed with the general linear ANOVA model procedure of SPSS 16.0 (SPSS Inc., Chicago, IL). In addition, a principal component analysis (PCA) was carried out to determine which variables were most influenced by drought and alkaline stresses and to determine how the data points following a given treatment (gender, drought or alkaline stress) were dispersed. Principal component analyses were performed using Canoco (version 4.5) for 17 variables: LMA, the RS ratio, the Fine/Course ratio, LAR, $\mathrm{SRL}_{\mathrm{f}}, P_{\mathrm{N}}, g_{\mathrm{s}}$, PNUE, N, N $\mathrm{T}, \mathrm{C}, \mathrm{NUE}, \mathrm{NUpE}, \mathrm{WUE}_{\mathrm{i}}$, $\delta^{13} \mathrm{C}, \delta^{15} \mathrm{~N}_{1}$, and $\delta^{15} \mathrm{~N}_{2}$.

Effects of drought and alkaline stress on photosynthetic parameters: $P_{\mathrm{N}}, g_{\mathrm{s}}$, and PNUE significantly decreased in both genders in response to drought and alkaline conditions individually, and a greater reduction occurred under the combination of both factors due to a 'drought $\times$ alkaline' interaction (Fig. $1 A-C$; Table 2). A significant 'sex $\times$ alkaline $\times$ drought' interaction reflected the different gender effects under drought and alkaline stress conditions, as the decreases in $P_{\mathrm{N}}, g_{\mathrm{s}}$, and PNUE were smaller in the males than that in the females (Table 2).

Effects of drought and alkaline stresses on nutrient concentrations: Leaf $\mathrm{N}$ and $\mathrm{C}$ concentrations and total plant $\mathrm{N}$ significantly decreased due to drought and alkalinity individually and by their combination in both genders, although significant 'drought $\times$ alkaline' interactive effects were observed only for leaf $\mathrm{C}$ concentrations (Fig. $2 A-C$; Table 2). Due to the 'sex $\times$ alkaline' interactive effects, significant gender differences in leaf $\mathrm{N}$ and $\mathrm{C}$ concentrations in response to alkalinity were observed, which was indicated by greater reductions in females than in males. At the same time, the 'sex $\times$ drought' interaction reflected the cumulative effects of both factors; this phenomenon was indicated by the stronger decrease of total plant $\mathrm{N}$ and leaf $\mathrm{C}$ concentrations in the females than that in the males (Table 2).

Effects of drought and alkaline stresses on nitrogen- and water-use efficiency: Drought and alkaline stress significantly affected NUE in females. In contrast, neither drought nor alkaline stress changed the NUE or $\mathrm{WUE}_{\mathrm{i}}$ in males, as indicated by the 'sex $\times$ alkaline' and/or 'sex $\times$ drought' interactive effects (Fig. 3A,C; Table 2). In comparison to drought and alkaline stress alone, stronger inhibition under the combination of both stresses was 


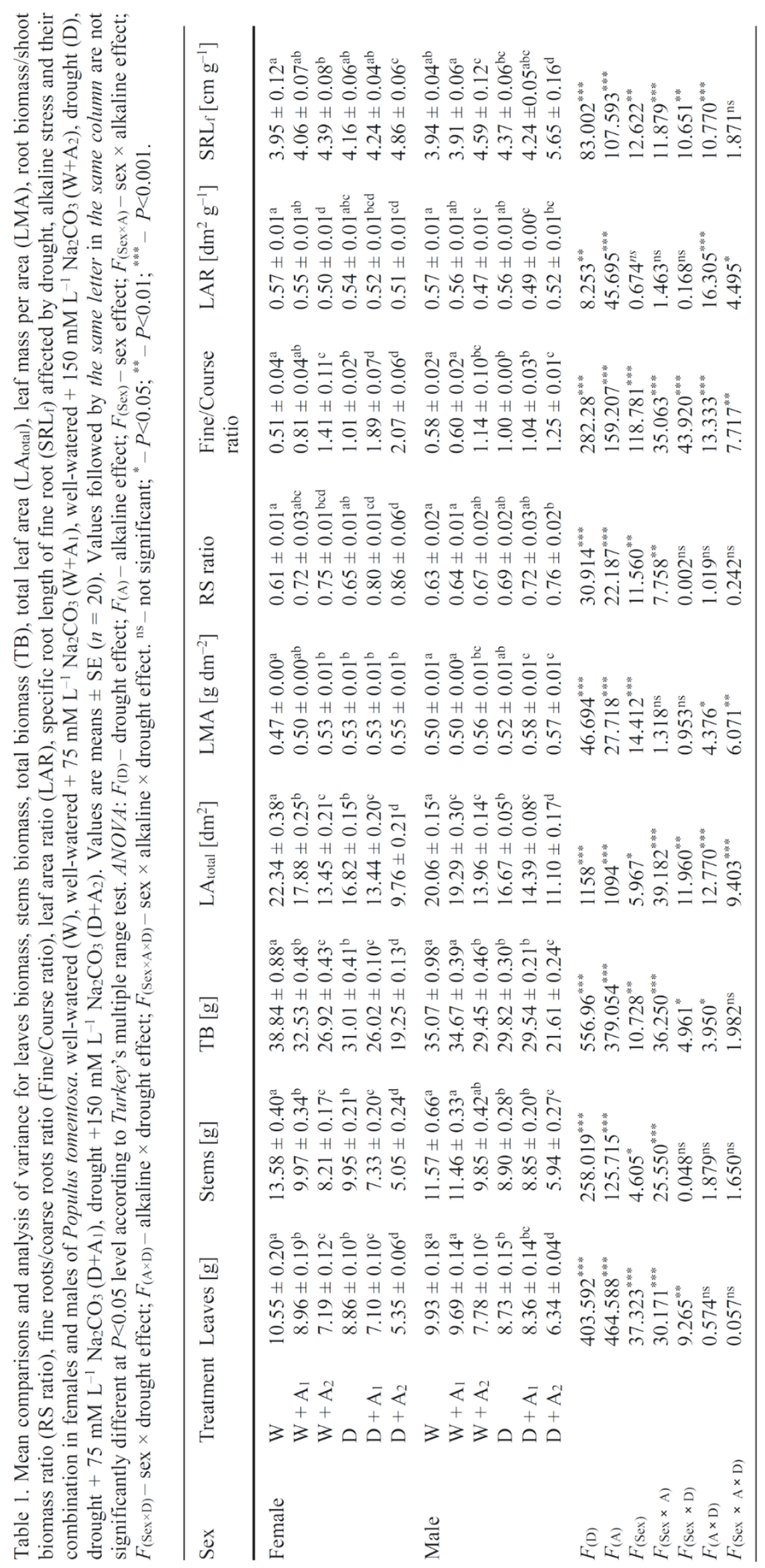




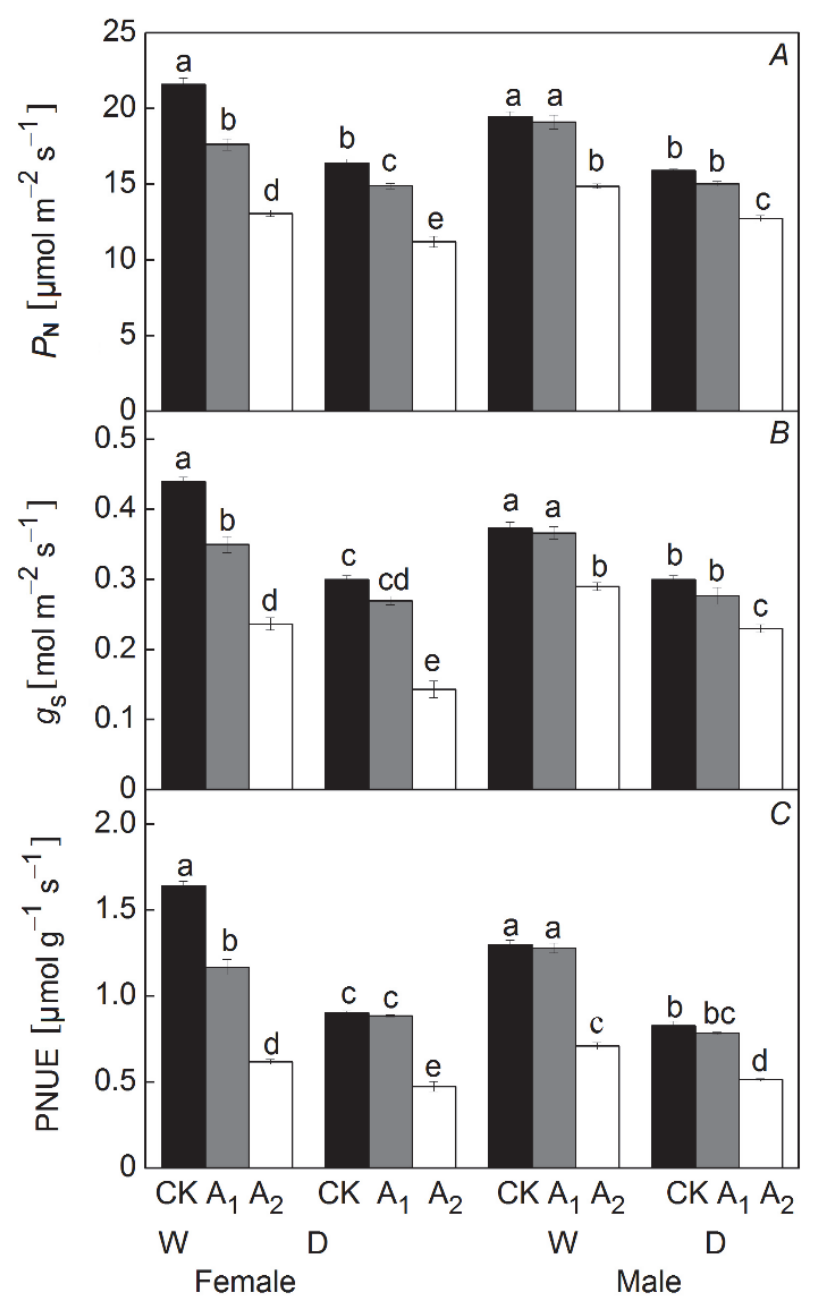

Fig. 1. The effects of alkaline and drought stress on net photosynthetic rate $\left(P_{\mathrm{N}} ; A\right)$, stomatal conductance $\left(g_{\mathrm{s}} ; B\right)$, and photosynthetic nitrogen-use efficiency (PNUE; $C$ ), in female and male Populus tomentosa cuttings. $\mathrm{CK}-$ control; $\mathrm{A}_{1}-75 \mathrm{mM}\left(\mathrm{Na}_{2} \mathrm{CO}_{3}\right)$ $\mathrm{L}^{-1} ; \mathrm{A}_{2}-150 \mathrm{mM}\left(\mathrm{Na}_{2} \mathrm{CO}_{3}\right) \mathrm{L}^{-1} ; \mathrm{W}$ - well-watered; D - drought. Values are presented as the means $\pm \operatorname{SE}(n=5)$. Values followed by different letters above the bars are significantly different at the $P<0.05$ level according to Tukey's multiple range test.

observed in NUpE, owing to the effect of the 'drought $\times$ alkaline' interaction. Gender differences in response to drought and alkaline stress were observed in the NUE and NUpE due to the 'sex $\times$ alkaline $\times$ drought' interaction: NUE was significantly affected by high alkaline conditions individually as well as by the combinations of both stresses in the females, while no effect was observed in the males (Fig. 3A, $B$; Table 2). NUpE significantly decreased under all treatments in the females, while low alkaline conditions had little effect on the males (Fig. 3B, Table 2).

Effects of drought and alkaline stresses on carbon and nitrogen isotope compositions: The $\delta^{13} \mathrm{C}$ content significantly increased in response to drought and alkaline stresses individually and in combination in females; however, this content was influenced by significant 'sex $\times$ alkaline' and 'sex $\times$ drought' interactions, resulting in a smaller increase in $\delta^{13} \mathrm{C}$ in the males (Fig. 4A, Table 2). Both $\delta^{15} \mathrm{~N}_{1}$ and $\delta^{15} \mathrm{~N}_{2}$ significantly decreased under all stress conditions in the females, while no changes in both parameters were observed under low or high alkaline stress individually in the males. As indicated by the 'sex $x$ alkaline' and/or 'sex $\times$ drought $\times$ alkaline' interactive effects, the $\delta^{15} \mathrm{~N}_{1}$ and $\delta^{15} \mathrm{~N}_{2}$ decreased more in the female cuttings than in the male cuttings (Fig. $4 B, C$; Table 2).

Table 2. Analysis of variance ( $F$ values) for the interactive effects of sex, drought, and alkaline stresses on net photosynthetic rate $\left(P_{\mathrm{N}}\right)$, stomatal conductance $\left(g_{\mathrm{s}}\right)$, photosynthetic nitrogen-use efficiency (PNUE), leaf $\mathrm{N}$ concentrations $(\mathrm{N})$, total plant $\mathrm{N}$ concentrations $\left(\mathrm{N}_{\mathrm{T}}\right)$, $\mathrm{N}$-use efficiency (NUE), N-uptake efficiency (NUpE), intrinsic water-use efficiency (WUE $)$, carbon isotope composition $\left(\delta^{13} \mathrm{C}\right)$, pretreated with ${ }^{15} \mathrm{NH}_{4} \mathrm{Cl}$ fertilizer $\left(\delta^{15} \mathrm{~N}_{1}\right)$ and pretreated with $\mathrm{Na}^{15} \mathrm{NO}_{3}$ fertilizer $\left(\delta^{15} \mathrm{~N}_{2}\right)$. Sex $\times \mathrm{D}-\operatorname{sex} \times \operatorname{drought}$ effect; Sex $\times \mathrm{A}-$ sex $\times$ alkaline effect; D $\times \mathrm{A}$ - drought $\times$ alkaline effect; Sex $\times \mathrm{D} \times \mathrm{A}-\operatorname{sex} \times$ drought $\times$ alkaline effect. ${ }^{\mathrm{ns}}$ - not significant; ${ }^{*}-P<0.05 ;{ }^{* *}-$ $P<0.01{ }^{* * *}-P<0.001$.

\begin{tabular}{llllllll}
\hline Parameter & Sex & D & A & Sex $\times$ D & Sex $\times$ A & D $\times$ A & Sex $\times$ D $\times$ A \\
\hline$P_{\mathrm{N}}$ & $5.476^{*}$ & $386.914^{* * *}$ & $365.885^{* * *}$ & $0.003^{\mathrm{ns}}$ & $28.145^{* * *}$ & $17.205^{* * *}$ & $6.805^{* * *}$ \\
$g_{\mathrm{s}}$ & $10.922^{* *}$ & $336.636^{* * *}$ & $224.299^{* * *}$ & $9.468^{* *}$ & $37.649^{* * *}$ & $3.364^{\mathrm{ns}}$ & $5.182^{*}$ \\
$\mathrm{PNUE}$ & $6.235^{* * *}$ & $967.561^{* * *}$ & $793.971^{* * *}$ & $0.472^{\mathrm{ns}}$ & $46.465^{* * *}$ & $105.446^{* * *}$ & $50.113^{* * *}$ \\
$\mathrm{~N}$ & $189.562^{* * *}$ & $385.432^{* * *}$ & $216.403^{* * *}$ & $3.106^{\mathrm{ns}}$ & $11.239^{* * *}$ & $0.568^{\mathrm{ns}}$ & $5.033^{*}$ \\
$\mathrm{~N}_{\mathrm{T}}$ & $38.423^{* * *}$ & $237.806^{* * *}$ & $89.709^{* * *}$ & $14.286^{* * *}$ & $0.554^{\mathrm{ns}}$ & $3.103^{\mathrm{ns}}$ & $0.554^{\mathrm{ns}}$ \\
$\mathrm{C}$ & $7.115^{* * * *}$ & $471.308^{* * *}$ & $211.913^{* * *}$ & $13.972^{* * *}$ & $18.421^{* * *}$ & $12.081^{* * *}$ & $0.238^{\mathrm{ns}}$ \\
$\mathrm{NUE}$ & $8.089^{* *}$ & $99.944^{* * *}$ & $22.734^{* * *}$ & $25.955^{* * *}$ & $11.680^{* * *}$ & $3.314^{\mathrm{ns}}$ & $4.718^{*}$ \\
$\mathrm{NUpE}$ & $33.240^{* * *}$ & $414.308^{* * *}$ & $137.103^{* * *}$ & $0.289^{\mathrm{ns}}$ & $1.945^{\mathrm{ns}}$ & $41.317^{* * *}$ & $6.858^{* *}$ \\
$\mathrm{WUE}_{\mathrm{i}}$ & $10.676^{* *}$ & $43.134^{* * *}$ & $19.283^{* * *}$ & $12.4^{* *}$ & $16.631^{* * *}$ & $5.633^{*}$ & $2.074^{\mathrm{ns}}$ \\
$\delta^{13} \mathrm{C}$ & $78.955^{* * *}$ & $427.029^{* * *}$ & $296.324^{* * *}$ & $31.763^{* * *}$ & $9.176^{* * *}$ & $2.066^{\mathrm{ns}}$ & $0.433^{\mathrm{ns}}$ \\
$\delta^{15} \mathrm{~N}_{1}$ & $179.188^{* * *}$ & $103.160^{* * *}$ & $55.455^{* * *}$ & $0.009^{\mathrm{ns}}$ & $6.227^{* *}$ & $1.145^{\mathrm{ns}}$ & $2.580^{\mathrm{ns}}$ \\
$\delta^{15} \mathrm{~N}_{2}$ & $87.480^{* * *}$ & $183.037^{* * *}$ & $49.300^{* * *}$ & $0.573^{\mathrm{ns}}$ & $7.247^{* *}$ & $4.038^{*}$ & $4.720^{*}$ \\
\hline
\end{tabular}




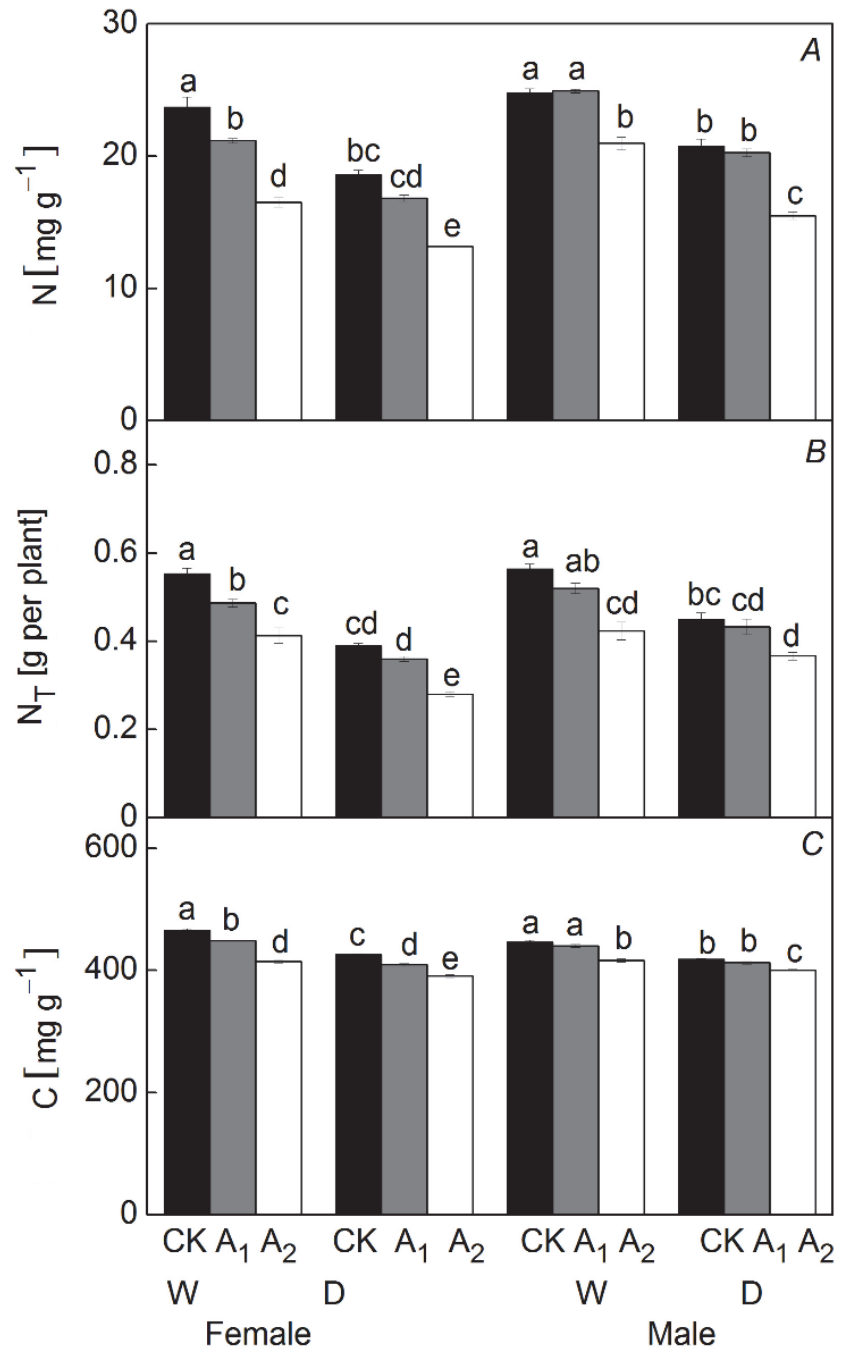

Fig. 2. The effects of alkaline and drought stresses on leaf $\mathrm{N}$ concentrations $(A)$, total plant $\mathrm{N}$ concentrations $\left(\mathrm{N}_{\mathrm{T}} ; B\right)$, and leaf $\mathrm{C}$ concentrations $(C)$ in female and male Populus tomentosa cuttings. CK - control; $\mathrm{A}_{1}-75 \mathrm{mM}\left(\mathrm{Na}_{2} \mathrm{CO}_{3}\right) \mathrm{L}^{-1} ; \mathrm{A}_{2}-150 \mathrm{mM}$ $\left(\mathrm{Na}_{2} \mathrm{CO}_{3}\right) \mathrm{L}^{-1}$; W - well-watered; $\mathrm{D}$ - drought. Values are presented as the means $\pm \operatorname{SE}(n=5)$. Values followed by different letters above the bars are significantly different at the $P<0.05$ level according to Tukey's multiple range test.

Plasticity analysis: For all drought and alkaline treatments, the values of the plasticity index (PI) were in the range of 0.022 to 0.752 (Fig. $5 A-F$ ). Although the Fine/Course ratio exhibited the greatest plasticity at the plant level, PNUE exhibited the greatest plasticity at the leaf level (Fig. $5 A-F$ ). In general, males exposed to drought and alkaline stresses presented lower PI values than did females for the $\mathrm{R} / \mathrm{S}$ ratio, the Fine/Course ratio, $\mathrm{N}_{\mathrm{T}}$, NUE, and NUpE for plant-level traits and for leaf $\mathrm{C}$ and $\mathrm{N}$ concentrations, $\mathrm{N}$ isotope composition, $P_{\mathrm{N}}, g_{\mathrm{s}}$, PNUE, and $\mathrm{WUE}_{\mathrm{i}}$ for leaf-level traits (Fig. 5A,B). In contrast, the males exhibited a higher plasticity than that of females regarding $\mathrm{SRL}_{\mathrm{f}}, \mathrm{LMA}$, and $\delta^{13} \mathrm{C}$ in response to drought and alkaline stresses (Fig. $5 A, B$ ).

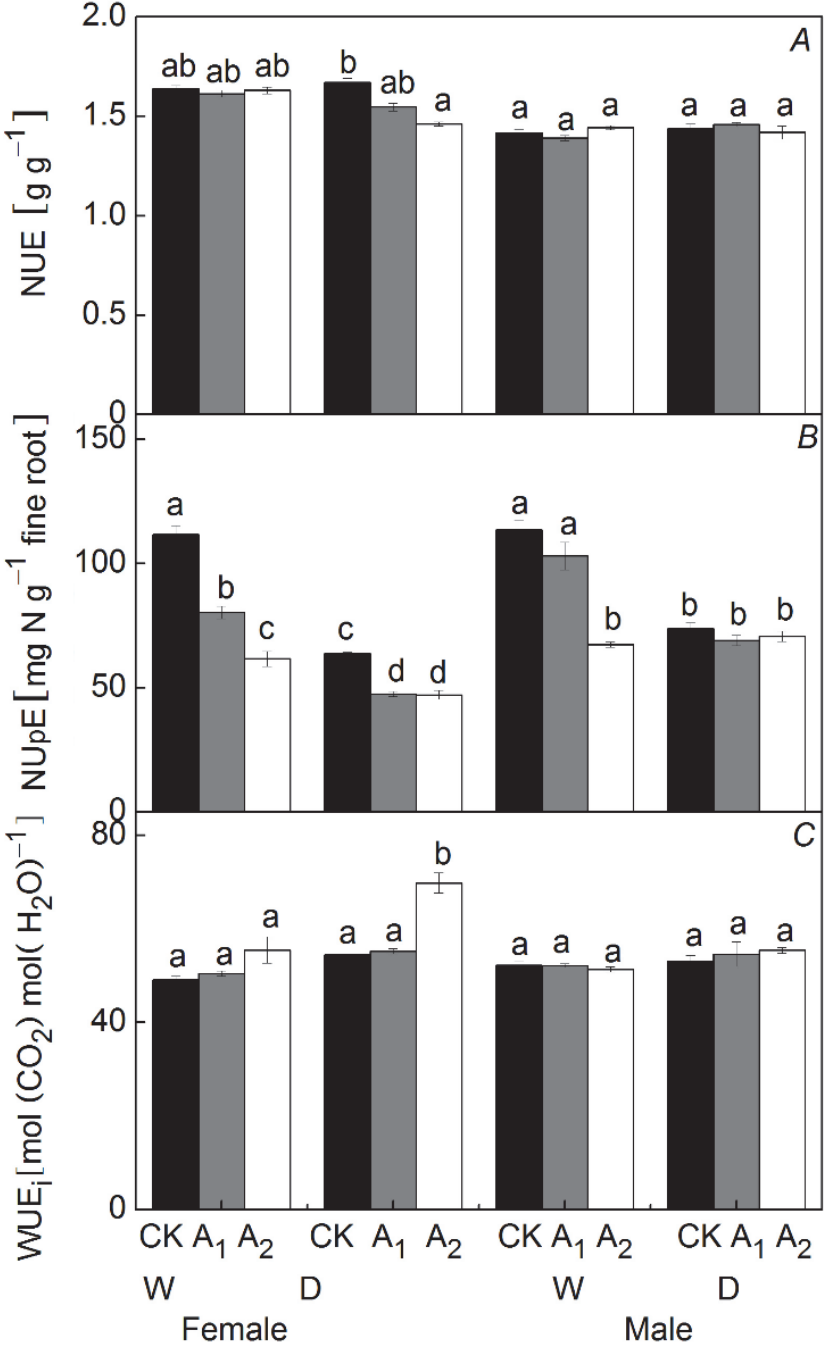

Fig. 3. The effects of alkaline and drought stresses on N-use efficiency (NUE; $A$ ); N-uptake efficiency (NUpE; $B$ ); and intrinsic water-use efficiency $\left(\mathrm{WUE}_{\mathrm{i}} ; C\right)$, in female and male Populus tomentosa cuttings. $\mathrm{CK}-$ control; $\mathrm{A}_{1}-75 \mathrm{mM}\left(\mathrm{Na}_{2} \mathrm{CO}_{3}\right)$ $\mathrm{L}^{-1} ; \mathrm{A}_{2}-150 \mathrm{mM}\left(\mathrm{Na}_{2} \mathrm{CO}_{3}\right) \mathrm{L}^{-1} ; \mathrm{W}$ - well-watered; $\mathrm{D}$ - drought. Values are presented as the means $\pm \mathrm{SE}(n=5)$. Values followed by different letters above the bars are significantly different at the $P<0.05$ level according to Tukey's multiple range test.

Trait correlations: The results of the principal component analysis showed a clear demarcation between genders under all treatment conditions (Fig. 6). The model explained $93.3 \%$ of the dataset's total variance for both sexes; the variance was loaded on two components (Fig. 6). The first main component (80.7\%) was strongly influenced by the LAR, $P_{\mathrm{N}}, g_{\mathrm{s}}$, PNUE, N, N $, \mathrm{C}, \mathrm{NUpE}$, $\delta^{15} \mathrm{~N}_{1}$, and $\delta^{15} \mathrm{~N}_{2}$ in both sexes, which were negatively correlated with LMA, SRL negatively correlated with the $\mathrm{R} / \mathrm{S}$ ratio, the Fine/Course ratio, and $\mathrm{WUE}_{\mathrm{i}}$ in the females. The second main component $(12.6 \%)$ was strongly influenced by the NUE of both sexes (Fig. 6). In addition, the $\mathrm{R} / \mathrm{S}$ ratio presents the smallest angle to the Fine/Course ratio and $\mathrm{WUE}_{\mathrm{i}}$ in 
the females, while LMA has the smallest angle to $\mathrm{SRL}_{\mathrm{f}}$ and $\delta^{13} \mathrm{C}$ in the males (Fig. 6). These results indicate that the RS ratio may have the closest connection with both the Fine/Course ratio and $\mathrm{WUE}_{\mathrm{i}}$ in the females and that LMA may have the closest connection with both $\mathrm{SRL}_{\mathrm{f}}$ and $\delta^{13} \mathrm{C}$ in the males. Compared with those under the control conditions, the females under low alkaline stress, high

\section{Discussion}

Our experiment was set to address drought and alkaline stress on the functional response of male and female $P$. tomentosa cuttings. Different trade-offs between growth and functional traits in response to both stresses were observed according to sex. In this study, compared to males, females presented a more significant increase in the $\mathrm{R} / \mathrm{S}$ ratio and Fine/Course ratio, suggesting that they should outcompete males under both stresses because they enhanced these parameters, as part of morphological responses, which might improve soil exploration and nutrient uptake (Paz et al. 2012). Nevertheless, the more significant reduction in $\mathrm{NUpE}, \delta^{15} \mathrm{~N}$ isotope composition, and leaf $\mathrm{C}$ and $\mathrm{N}$ concentrations observed in females compared to males contradicts this hypothesis. The reduced capacity for $\mathrm{N}$ uptake occurred mainly due to limitations created by water and alkaline stress on root development, especially that of the fine roots. As a costly process, $\mathrm{N}$ uptake requires vast energy consumption, accompanied by a high protein turnover and assimilation (Bouma et al. 1996, Adams et al. 2013). In the present study, the more pronounced increase in $\mathrm{SRL}_{\mathrm{f}}$ and LMA observed in males than that in females is consistent with increased fitness under drought and alkaline stresses. $\mathrm{SRL}_{\mathrm{f}}$ is closely associated with the high-cost process of increasing root length or surface area and changes in root proliferation and life span (Eissenstat et al. 2000, McCormack et al. 2012). The results of theoretical analysis have shown that plant species with high root $\mathrm{SRL}_{\mathrm{f}}$ are more active in nutrient acquisition (Yanai et al. 1995, Eissenstat and Yanai 1997). In addition, increased LMA may reflect the accumulation of cell-wall compounds and non-structural carbohydrates, which determines the fitness of species in their environment and affects various ecosystem processes (Poorter et al. 2009). In similar circumstances, much tougher leaves have been observed.

Water-use efficiency (WUE) is represented as the $W E_{i}$ called intrinsic water-use efficiency, defined as the rate of $P_{\mathrm{N}}$ to $g_{\mathrm{s}}$, and the $\delta^{13} \mathrm{C}$ isotopic composition is represented as an integrated measure of WUE (Farquhar $e t$ al. 1989). WUE $\mathrm{E}_{\mathrm{i}}$ significantly increased only in response to high alkaline conditions in females; for all other treatments and in males, no marked changes were observed. These data contradict the isotopic $\mathrm{C}^{13} / \mathrm{C}^{12}$ data, which showed significant increases (less negative values) under all stress conditions for both genders. In addition, $\delta^{13} \mathrm{C}$ provides an integrated measurement of the internal alkaline stress, drought stress, drought plus low alkaline stress, and drought plus high alkaline stress conditions exhibited differences, while the males under drought plus high alkaline stress conditions exhibited differences, which indicated that the females were more influenced by drought and alkaline stresses than the males.

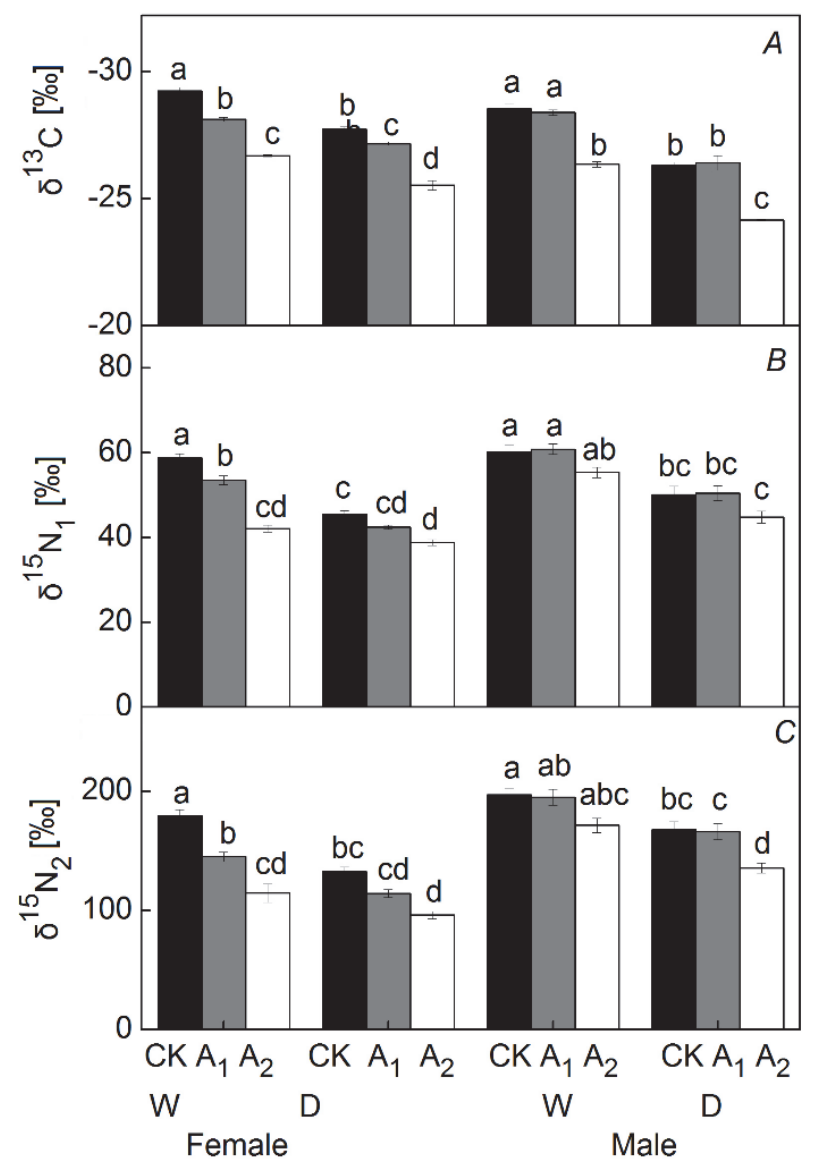

Fig. 4. The effects of alkaline and drought stresses on carbon isotope composition $\left(\delta^{13} \mathrm{C}, A\right)$; pretreatment with ${ }^{15} \mathrm{NH}_{4} \mathrm{Cl}$ fertilizer $\left(\delta^{15} \mathrm{~N}_{1} ; B\right)$; and pretreatment with $\mathrm{Na}^{15} \mathrm{NO}_{3}$ fertilizer $\left(\delta^{15} \mathrm{~N}_{2} ; C\right)$, in female and male Populus tomentosa cuttings. CK - control; $\mathrm{A}_{1}-75 \mathrm{mM}\left(\mathrm{Na}_{2} \mathrm{CO}_{3}\right) \mathrm{L}^{-1} ; \mathrm{A}_{2}-150 \mathrm{mM}\left(\mathrm{Na}_{2} \mathrm{CO}_{3}\right) \mathrm{L}^{-1}$; $\mathrm{W}$ - well-watered; D - drought. Values are presented as the means $\pm \operatorname{SE}(n=5)$. Values followed by different letters above the bars are significantly different at the $P<0.05$ level according to Tukey's multiple range test.

physiological and external environmental properties influencing photosynthetic gas exchange during a long period of time, while instantaneous water-use efficiency $\left(\mathrm{WUE}_{\mathrm{i}}\right)$, which is the ratio of $P_{\mathrm{N}}$ to $g_{s}$, is dependent on the instantaneous microclimate environment of each leaf position. 


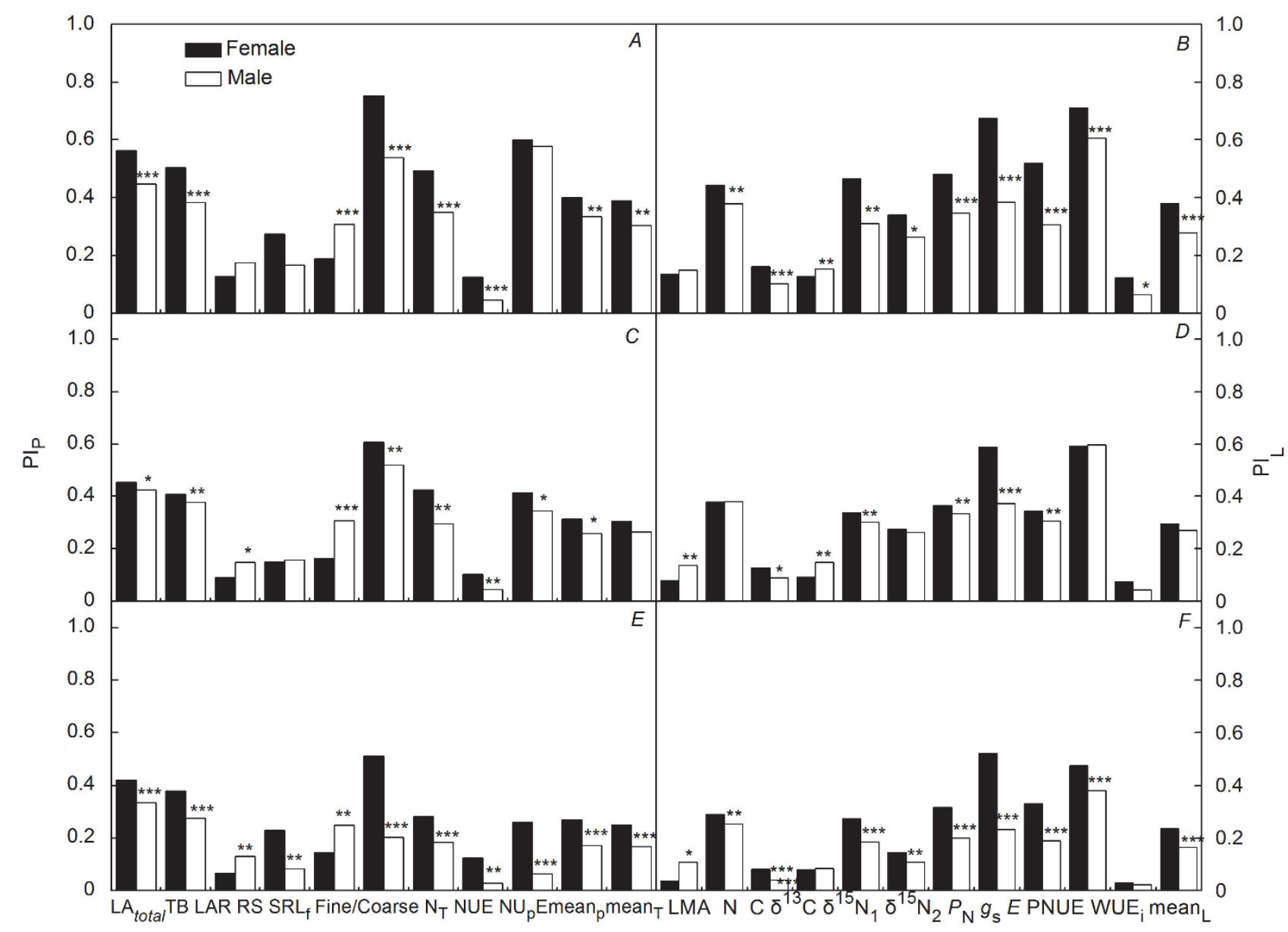

Fig. 5. Plasticity indices for leaf-level (PIL) and plant-level (PIP) traits measured in female and male Populus tomentosa cuttings in response to $(A, B)$ all treatments, $(C, D)$ alkaline stress, and $(E, F)$ drought stress $(n=4$ per traits per gender). Leaf-level traits: LMA - leaf mass per area; $\mathrm{N}$ - leaf nitrogen concentrations; $\mathrm{C}$ - leaf carbon concentration; $\delta^{13} \mathrm{C}$ - carbon isotope composition; $\delta^{15} \mathrm{~N}_{1}$ - pretreated with ${ }^{15} \mathrm{NH} 4 \mathrm{Cl}$ fertilizer; $\delta^{15} \mathrm{~N}_{2}$ - pretreated with $\mathrm{Na}^{15} \mathrm{NO}_{3}$ fertilizer; $P_{\mathrm{N}}$ - net photosynthetic rate; $g_{\mathrm{s}}$ - stomatal conductance; PNUE - photosynthetic nitrogen-use efficiency; WUE - intrinsic water-use efficiency; and MeanL - the means of leaflevel variables. Plant-level traits: LAtotal - total leaf area; TB - total biomass, LAR - leaf area ratio; R/S ratio - root biomass/shoot biomass ratio; $\mathrm{SRL}_{\mathrm{f}}$ - the ratio of fine root length to dry mass of fine roots; Fine/Course - fine roots/coarse roots ratio; $\mathrm{N}_{\mathrm{T}}-$ total plant nitrogen concentrations; NUE - nitrogen-use efficiency, NUpE - nitrogen-uptake efficiency; Mean $\mathrm{P}$ - the means of plant-level variables and Mean $\mathrm{T}$ - the total mean. ${ }^{\mathrm{ns}}$ - not significant; ${ }^{*}-P<0.05 ;{ }^{* *}-P<0.01 ;{ }^{* * *}-P<0.001$.

Nitrogen-use efficiency (NUE) was indicated by photosynthetic nitrogen-use efficiency (PNUE), $\delta^{15} \mathrm{~N}_{1}$, and $\delta^{15} \mathrm{~N}_{2}$ measured at the leaf level (Field et al. 1983, Valladares et al. 2000, Renninger et al. 2014) and by $\mathrm{NUpE}$ at the plant level (Berendse and Aerts 1987, Peñuelas et al. 2000). As expected, the females showed a significant reduction in all these parameters in response to drought and alkaline stresses, while the males showed only minor changes. This differential performance could be detrimental for females to be settled under conditions of water and alkalinity stress. Therefore, compared to the males, females have been referred to have higher reproduction costs, resulting in a greater demand for $\mathrm{N}$, which is a vital limiting factor for reproduction (McDowell et al. 2000, Obeso 2002).

The combination of water and alkaline stresses might generate conflicting demands on limited resources. By varying water and alkalinity supplies, a trade-off between leaf $\delta^{13} \mathrm{C}$ and leaf-level NUE (indicated by PNUE, $\delta^{15} \mathrm{~N}_{1}$, and $\delta^{15} \mathrm{~N}_{2}$ ) was observed for both genders of $P$. tomentosa and across all water and alkalinity treatments. This tradeoff arose from the physiological balance in which open stomata increased the rate of photosynthesis per unit of leaf $\mathrm{N}$ (high NUE) but resulted in large water losses (low WUE; Ripullone et al. 2004, Dijkstra et al. 2016). This apparently contrasting relationship is supported by the microeconomic framework in that the studied P. tomentos $a$ cuttings might maximize either their WUE or PNUE, depending on which resource is more limiting, similar to the manner in which Ulmus americana seedlings respond to nitrogen and water deficiency (Reich et al. 1989) and Quercus douglasii responds to summer drought and high temperatures (Xu and Baldocchi 2003). In addition to the trade-off between NUE and WUE at the leaf level, 


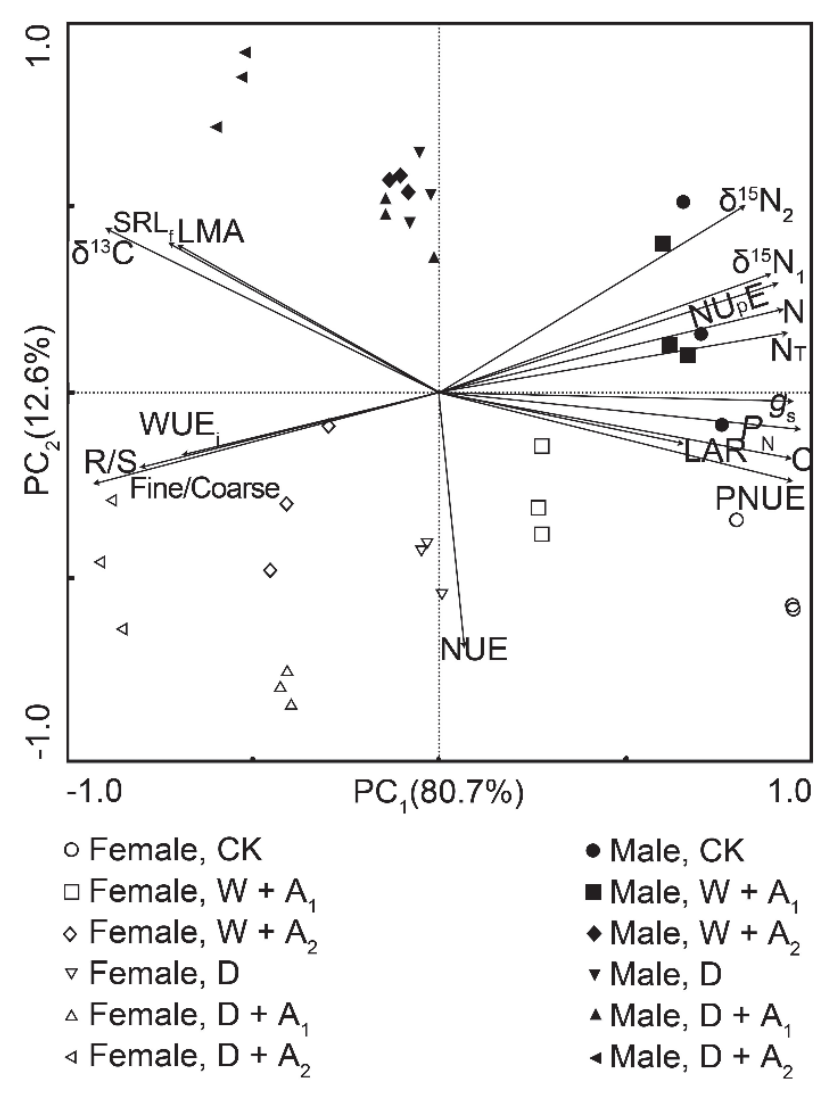

Fig. 6. Principal component analysis of Populus tomentosa males and females showing the relationships between 17 variables under different treatment combinations. C - leaf carbon concentration; Fine/Course - fine roots/coarse roots ratio; $g_{\mathrm{s}}-$ stomatal conductance; LAR - leaf area ratio; LMA - leaf mass per area; $\mathrm{N}$ - leaf nitrogen concentrations; $\mathrm{N}_{\mathrm{T}}$ - total plant nitrogen concentrations; NUE - nitrogen-use efficiency, $\mathrm{NU}_{\mathrm{p}} \mathrm{E}-$ nitrogen-uptake efficiency; $P_{\mathrm{N}}-$ net photosynthetic rate; PNUE - photosynthetic nitrogen-use efficiency; R/S - root biomass/shoot biomass ratio; $\mathrm{SRL}_{\mathrm{f}}$ - the ratio of fine root length to dry mass of fine roots; $\mathrm{WUE}_{\mathrm{i}}$ - intrinsic water-use efficiency; $\delta^{13} \mathrm{C}$ - carbon isotope composition; $\delta^{15} \mathrm{~N}_{1}$ - pretreated with ${ }^{15} \mathrm{NH}_{4} \mathrm{Cl}$ fertilizer; $\delta^{15} \mathrm{~N}_{2}$ - pretreated with $\mathrm{Na}^{15} \mathrm{NO}_{3}$ fertilizer. CK - control; $\mathrm{W}+\mathrm{A}_{1}-$ well-watered $+75 \mathrm{mM}\left(\mathrm{Na}_{2} \mathrm{CO}_{3}\right) \mathrm{L}^{-1} ; \mathrm{W}+\mathrm{A}_{2}-$ well-watered $+150 \mathrm{mM}\left(\mathrm{Na}_{2} \mathrm{CO}_{3}\right) \mathrm{L}^{-1} ; \mathrm{D}$ - drought; $\mathrm{D}+\mathrm{A}_{1}-$ drought $+75 \mathrm{mM}\left(\mathrm{Na}_{2} \mathrm{CO}_{3}\right) \mathrm{L}^{-1} ; \mathrm{D}+\mathrm{A}_{2}-$ drought +150 $\mathrm{mM}\left(\mathrm{Na}_{2} \mathrm{CO}_{3}\right) \mathrm{L}^{-1}$.

the trade-off between WUE and NUpE was maintained at the whole-plant level. Although the allocation of $\mathrm{N}$ may differ within a plant (Garrish et al. 2010), a relationship between NUE and WUE at the whole-plant level was also observed. In contrast, when we used WUE $\mathrm{E}_{\mathrm{i}}$ instead of $\delta^{13} \mathrm{C}$, the trade-off between WUE and NUE was observed only

\section{References}

Adams T.S., McCormack M.L., Eissenstat D.M.: Foraging strategies in trees of different root morphology: the role of root lifespan. - Tree Physiol. 33: 940-948, 2013.

Behnke K., Ghirardo A., Janz D.I. et al.: Isoprene function in two in the $P$. tomentosa females; neither in response to drought nor alkalinity the changes occurred in WUE and NUE in males.

Phenotypic plasticity is a common mechanism adopted by plants to optimize resource acquisition and is consistent with the expectation that the responses of $P$. tomentosa cuttings are affected by water and alkaline stresses (WestEberhard 1989, Sultan 1992). It seems that much higher values of PI indicate much higher sensitivity to drought and alkalinity. Inferred from the PCA, the LAR, $P_{\mathrm{N}}, g_{\mathrm{s}}$, PNUE, $\mathrm{N}, \mathrm{N}_{\mathrm{T}}, \mathrm{C}, \mathrm{NUpE}, \delta^{15} \mathrm{~N}_{1}$, and $\delta^{15} \mathrm{~N}_{2}$ were shown to play a leading role in the adaptations of both genders in response to both stresses. However, the magnitude of plasticity can vary among species and traits. According to Bonger et al. (2002), the higher the plasticity of traits, the more crucial the trait is for functioning. When the results of the PCA and the PI values were combined, the LMA, $\mathrm{SRL}_{\mathrm{f}}$, and $\delta^{13} \mathrm{C}$ of males and the $\mathrm{R} / \mathrm{S}$ ratio, the Fine/Course ratio, and $\mathrm{WUE}_{\mathrm{i}}$ of females were regarded as the most important functional traits for each gender with respect to obtaining sufficient water and nutrients in resource-poor environments. However, the plasticity of growth traits highly depends on age and size; thus, the experimental approach used in the present study could not provide information concerning the plasticity of large, adult trees.

Conclusion: Female and male $P$. tomentosa trees adopted different trade-offs between growth and stress defence to drought and alkaline stresses, and such a behaviour might occur due to the high cost of retaining high plasticity, highenergy-consumption requirements, and low-energy synthesis under stress conditions. Nevertheless, male $P$. tomentosa trees are more tolerant than the female ones, which we realized from the phenotypic canalization, except for the R/S ratio, the Fine/Course ratio, and $\mathrm{WUE}_{\mathrm{i}}$. However, the trade-off between growth and stress defence may depend on the life stage of a plant, as reported by Dudley (2006). As such, the physiological or growth reduction owing to the costs of reproduction may be more evident in young plantlets than in mature trees if resource translocation occurs among shoots to reproductive organs. The results of our studies were obtained only from nonreproductive cuttings; additional study should concentrate on reproductive growth. Furthermore, given the extensive contact between plastic phenotypes and plant function (Guo et al. 2008, Li et al. 2010), much attention should be focused on the combination of data from laboratory studies and from field applications in order to guide protection and management of dioecious trees in future applications.

contrasting poplars under salt and sunflecks. - Tree Physiol. 33: 562-578, 2013 .

Berendse F., Aerts R.: Nitrogen-use-efficiency: a biologically meaningful definition? - Funct Ecol. 1: 293-296, 1987. 
Bernacchi C.J., Thompson J.N., Coleman J.S. et al.: Allometric analysis reveals relatively little variation in nitrogen versus biomass accrual in four plant species exposed to varying light, nutrients, water and $\mathrm{CO}_{2}$. - Plant Cell Environ. 30: 1216-1222, 2007.

Bonal D., Sabatier D., Montpied P. et al.: Interspecific variability of $\delta^{13} \mathrm{C}$ among trees in rainforests of French Guiana: functional groups and canopy integration. - Oecologia 124: 454-468, 2000.

Bongers F., Schnitzer S.A., Traore D.: The importance of lianas and consequences for forest management in west Africa. Bioterre 1: 59-70, 2002.

Bouma T.J., Broekhuysen A.G.M., Veen B.W.: Analysis of root respiration of Solanum tuberosum as related to growth, ion uptake, and maintenance of biomass. - Plant Physiol. Bioch. 34: 795-806,1996.

Cepeda-Cornejo V., Dirzo R.: Sex-related differences in reproductive allocation, growth, defense and herbivory in three dioecious neotropical palms. - PLoS ONE 5: e9824, 2010.

Chen J., Dong T.F., Duan B.L.et al.: Sexual competition and N supply interactively affect the dimorphism and competiveness of opposite sexes in Populus cathayana. - Plant Cell Environ. 38: 1285-1298, 2015.

Dawson T.E., Bliss L.C.: Patterns of water use and tissue water relations in the dioecious shrub, Salix arctica: the physiological basis for habitat partitioning between the sexes. - Oecologia 79: 332-343, 1989.

Dawson T.E., Ehleringer J.R.: Gender-specific physiology, carbon isotope discrimination, and habitat distribution in discrimination, and habitat distribution in boxelder, Acer negundo. - Ecology 74: 798-815, 1993.

Dawson T.E., Geber M.A.: Sexual dimorphism in physiology and morphology. - In: Geber M.A., Dawson T.E., Delph L.F. (ed.): Gender and Dimorphism of Flowering Plants. Pp. 175-216. Springer, Berlin 1999.

Delph L.F.: Sex-differential resource-allocation patterns in the subdioecious shrub Hebe subalpina. - Ecology 71: 1342-1351, 1990.

Dijkstra F.A., Carrillo Y., Aspinwall M.J. et al.: Water, nitrogen and phosphorus use efficiencies of four tree species in response to variable water and nutrient supply. - Plant Soil 406: 187199, 2016.

Dong T.F., Li J.Y., Zhang Y.B. et al.: Partial shading of lateral branches affects growth, and foliage nitrogen- and water-use efficiencies in the conifer Cunninghamia lanceolata growing in a warm monsoon climate. - Tree Physiol. 35: 632-643, 2015.

Dudley L.S.: Ecological correlates of secondary dimorphism in Salix glauca (Salicaceae). - Am. J. Bot. 93: 1775-1783, 2006.

Eissenstat D.M., Yanai R.D.: The ecology of root lifespan. Adv. Ecol. Res. 27: 1-60, 1997.

Eissenstat D.M., Wells C.E., Yanai R.D. et al.: Building roots in a changing environment: implications for root longevity. New Phytol. 147: 33-42, 2000.

Farquhar G.D., Ehleringer J.R., Hubick K.T.: Carbon isotope discrimination and photosynthesis. - Annu. Rev. Plant Phys. 40: 503-537, 1989.

Field C., Merino J., Mooney H.A.: Compromises between wateruse efficiency and nitrogen-use efficiency in five species of California evergreens. - Oecologia 60: 384-389, 1983.

Garrish V., Cernusak L.A., Winter K. et al.: Nitrogen to phosphorus ratio of plant biomass versus soil solution in atropical pioneer tree, Ficus insipida. - J. Exp. Bot. 61: 3735$3748,2010$.
Geber M.A., Dawson T.E., Delph L.F.: Gender and Sexual Dimorphism in Flowering Plants. Pp. 217-246. Springer, Berlin 1999.

Godoy O., Valladares F., Castro-Díez P.: Multispecies comparison reveals that invasive and native plants differ in their traits but not in their plasticity. - Funct. Ecol. 25: 1248-1259, 2011.

Guo D.L., Xia M.X., Wei X. et al.: Anatomical traits associated with absorption and mycorrhizal colonization are linked to root branch order in twenty-three Chinese temperate tree species. - New Phytol. 180: 673-683, 2008.

Hawkins B.J.: Family variation in nutritional and growth traits in Douglas-fir seedlings. - Tree Physiol. 27: 911-919, 2007.

He C.Z., Zhang Z.Y., Feng X.L. et al.: Variation of leaf characteristics in Populus tomentosa Carr. - For. Stud. China 7: 51-53, 2005. [In Chinese]

James J.J., Tiller R.L., Richards J.H.: Multiple resources limit plant growth and function in a saline-alkaline desert community. - J. Ecol. 93: 113-126, 2005.

Kalcsits L.A., Min X., Guy R.D.: Interspecific variation in leafroot differences in $\delta^{15} N$ among three tree species grown with either nitrate or ammonium. - Trees 29: 1069-1078, 2015.

Li A., Guo D.L., Wang Z.Q. et al.: Nitrogen and phosphorus allocation in leaves, twigs, and fine roots across 49 temperate, subtropical and tropical tree species: a hierarchical pattern. Funct. Ecol. 24: 224-232, 2010.

Li C.Y., Berninger F., Koskela J. et al.: Drought responses of Eucalyptus microtheca provenances depend on seasonality of rainfall in their place of origin. - Aust. J. Plant Physiol. 27: 231-238, 2000

Li C.Y, Yin C.Y., Liu S.: Different responses of two contrasting Populus davidiana populations to exogenous abscisic acid application. - Environ. Exp. Bot. 51: 237-246, 2004.

Li Y., Duan B.L., Chen J. et al.: Males exhibit competitive advantages over females of Populus deltoides under salinity stress. - Tree Physiol. 36: 1573-1584, 2016.

Lu Y.W., Wang G.Q., Meng Q.J. et al.: Growth and physiological responses to arbuscular mycorrhizal fungi and salt stress in dioecious plant Populus tomentosa. - Can. J. Forest Res. 44: 1020-1031, 2014.

McCormack M.L., Adams T.S., Smithwick E.A.H. et al.: Predicting fine root lifespan from plant functional traits in temperate trees. - New Phytol. 195: 823-831, 2012.

McDowell N., Marshall J., Hooker T. et al.: Estimating $\mathrm{CO}_{2}$ flux from snowpacks at three sites in the Rocky Mountains. - Tree Physiol. 20: 745-753, 2000.

Millard P., Grelet G.-A.: Nitrogen storage and remobilization by trees: ecophysiological relevance in a changing world. - Tree Physiol. 30: 1083-1095, 2010.

Mitchell A.K.: Acclimation of Pacific yew (Taxus brevifolia) foliage to sun and shade. - Tree Physiol. 18: 749-757, 1998.

Montesinos D., Villar-Salvador P., García-Fayos P. et al.: Genders in Juniperus thurifera have different functional responses to variations in nutrient availability. - New Phytol. 193: 705-712, 2012.

Munns R.: Plant adaptations to salt and water stress: differences and commonalities. - Adv. Bot. Res. 57: 1-32, 2011.

Nelson D.W., Sommers L.E.: Total carbon, organic carbon and organic matter. - In: Page A.L., Miller R.H., Keeney D.R. (ed.) Methods of Soil Analysis, Part 2. Chemical and Microbio logical Properties. Pp. 539-579. American Society of Agronomy, Madison 1982.

Obeso J.R.: The cost of reproduction in plants. - New Phytol. 155: 321-348, 2002 
Ometto J.P.H.B., Ehleringer J.R., Domingues T.F. et al.: The stable carbon and nitrogen isotopic composition of vegetation in tropical forests of the Amazon Basin, Brazil. Biogeochemistry 79: 251-274, 2006.

Ortiz P.L., Arista M., Talavera S.: Sex ratio and reproductive effort in the dioecious Juniperus communis subsp alpina (Suter) Celak. (Cupressaceae) along an altitudinal gradient. Ann Bot.-London 89: 205-211, 2002.

Paz E.Y., Gil K., Rebolledo L. et al.: Genetic diversity of Cuban pineapple germplasm assessed by AFLP markers. - Crop Breed. Appl. Biotechnol. 12: 104-110, 2012.

Peñuelas J., Filella I., Lloret F. et al.: Effects of a severe drought on water and nitrogen use by Quercus ilex and Phillyrea latifolia. - Biol. Plantarum 43: 47-53, 2000.

Poorter H., Niinemets U., Poorter L. et al.: Causes and consequences of variation in leaf mass per area (LMA): a metaanalysis. - New Phytol. 182: 565-588, 2009.

Randriamanana T.R., Nybakken L., Lavola A. et al.: Sex-related differences in growth and carbon allocation to defence in Populus tremula as explained by currrent plant defence theories. - Tree Physiol. 34: 471-487, 2014.

Rao P.S., Mishra B., Gupta S.R. et al.: Reproductive stage tolerance to salinity and alkalinity stresses in rice genotypes. Plant Breed. 127: 256-261, 2008.

Reich P.B., Walters M.B., Tabone T.J.: Response of Ulmus americana seedlings to varying nitrogen and water status. Water and nitrogen use efficiency in photosynthesis. - Tree Physiol. 5: 173-184,1989.

Renner S.S., Ricklefs R.E.: Dioecy and its correlates in the flowering plants. - Am. J. Bot. 82: 596-606, 1995.

Renninger H.J., Carlo N., Clark K.L. et al.: Physiological strategies of co-occurring oaks in a water- and nutrient-limited ecosystem. - Tree Physiol. 34: 159-173, 2014.

Ripullone F., Lauteri M., Grassi G. et al.: Variation in nitrogen supply changes water-use efficiency of Pseudotsuga menziesii and Populus $\mathrm{x}$ euroamericana; a comparison of three approaches to determine water-use efficiency. - Tree Physiol. 24: 671-679, 2004.
Stehlik I., Friedman J., Barrett S.C.H.: Environmental influence on primary sex ratio in a dioecious plant. - P. Natl. Acad. Sci. USA 105: 10847-10852, 2008.

Sudmeyer R.A., Speijers J., Nicholas B.D.: Root distribution of Pinus pinaster, P. radiata, Eucalyptus globulus and E. kochii and associated soil chemistry in agricultural land adjacent to tree lines. - Tree Physiol. 24: 1333-1346, 2004.

Sultan S.E.: What has survived of Darwin's theory? Phenotypic plasticity and the Neo-Darwinian legacy. - Evol. Trend Plant 6: $61-71,1992$

Valladares F., Wright S.J., Lasso E. et al.: Plastic phenotypic response to light of 16 congeneric shrubs from a Panamanian rainforest. - Ecology 81: 1925-1936, 2000.

Valladares F., Sánchez-Gómez D., Zavala M.A.: Quantitative estimation of phenotypic plasticity: bridging the gap between the evolutionary concept and its ecological applications. - J. Ecol. 94: 1103-1116, 2006.

Wanek W., Zotz G.: Are vascular epiphytes nitrogen or phosphorus limited? A study of plant $\left({ }^{15}\right) \mathrm{N}$ fractionation and foliar N:P stoichiometry with the tank bromeliad Vriesea sanguinolenta. - New Phytol. 192: 462-470, 2011.

West-Eberhard M.J.: Phenotypic plasticity and the origins of diversity. - Annu. Rev. Ecol. Syst. 20: 249-278,1989.

West-Eberhard M.J.: Developmental Plasticity and Evolution. Pp. 816. Oxford Univ. Press, New York 2003.

$\mathrm{Xu}$ L.K., Baldocchi D.D.: Seasonal trends in photosynthetic parameters and stomatal conductance of blue oak (Quercus douglasii) under prolonged summer drought and high temperature. - Tree Physiol. 23: 865-877, 2003.

Yanai R.D., Fahey T.J., Miller L.: Efficiency of nutrient acquisition by fine roots and mycorrhizae. - In: Smith W., Hinckley T.M. (ed.): Resource Physiology of Conifers. Pp. 75103. Academic Press, New York 1995.

Zhao H., Li Y., Zhang X. et al.: Sex-related and stagedependent source-to-sink transition in Populus cathayana grown at elevated $\mathrm{CO}_{2}$ and elevated temperature. - Tree Physiol. 32:1325-1338, 2012. 